Vol. 1 No. 3 Desember 2021, e-ISSN : 2797-8842 | p-ISSN : 2797-9431

\title{
INTERNALISASI FILOSOFI PENDIDIKAN KI HAJAR DEWANTARA DALAM MEWUJUDKAN PROFIL PELAJAR PANCASILA
}

\author{
FAJAR RAHAYUNINGSIH \\ SMK Negeri 1 Kokap \\ e-mail: fajarrahayuningsih2015@gmail.com
}

\begin{abstract}
ABSTRAK
Pelajar Pancasila adalah perwujudan pelajar Indonesia sebagai pelajar sepanjang hayat yang memiliki kompetensi global dan berperilaku sesuai dengan nilai-nilai Pancasila dengan enam ciri utama : beriman, bertakwa kepada Tuhan Yang Maha Esa, dan berakhlak mulia, berkebhinekaan global, bergotong royong, mandiri, bernalar kritis dan kreatif.Pendidikan karakter dalam pembentukan profil pelajar Pancasila sebenarnya sudah diupayakan, baik dalam proses pembelajaran di dalam kelas maupun diluar kelas. Rumusan profil Pelajar Pancasila dibuat dengan tujuan sebagai kompas bagi pendidik dan pelajar Indonesia. Segala pembelajaran, program, dan kegiatan disatuan pendidikan bertujuan akhir ke profil pelajar Pancasila. Upaya-upaya tersebut dapat dilakukan melalui keteladanan dan pembiasaan yang dalam pelaksanaannya tak lepas dari tuntunan seorang guru (pamong). Sesuai dengan semboyan Ki Hajar Dewantara "ing ngarso sung tulodo, ing madya mangun karso, tut wuri handayani yang artinya di depan menjadi teladan, ditengah membangun semangat di belakang memberikan dorongan". Dari hasil studi literatur ditemukan bahwa pemikiran Ki Hajar Dewantara tentang Pendidikan sangat relevan diterapkan dimana menurut beliau bahwa pendidikan merdeka itu berdaya upaya dengan sengaja untuk memajukan hidup dan tumbuhnya budi pekerti (rasa, fikiran, rokh) dan badan anak dengan jalan pengajaran, teladan, dan pembiasaan jangan disertai perintah dan paksaan. Pemikiran ini sejalan dengan mandat dari Presiden Republik Indonesia yang tertuang dalam Peraturan menteri Pendidikan dan Kebudayaan No 20 Tahun 2018 tentang penetapan profil pelajar Pancasila. Profil pelajar Pancasila bertujuan mendukung Visi dan Misi Presiden untuk mewujudkan Indonesia Maju yang berdaulat, mandiri dan berkepribadian. Perwujudan pelajar Indonesia sebagai pelajar sepanjang hayat yang memiliki kompetensi global dan berperilaku sesuai dengan nilai-nilai Pancasila Penelitian ini merupakan penelitian yang menggunakan meode penelitian pustaka (library research), yang meliputi kegiatan mencari, membaca, dan menelaah laporan-laporan penelitian dan bahan pustaka yang memuat teori-teori yang relevan dengan penelitian yang kan dilakukan. Harapan dari study literatur ini mampu menunjukkan Internalisasi Filosofi pendidikan Ki Hajar Dewantara dalam mewujudkan Profil Pelajar Pancasila
\end{abstract}

Kata Kunci: Profil Pelajar Pancasila, Filososfi Ki Hajar Dewantara, Pendidikan karakter

\section{ABSTRACT}

Pancasila students are the embodiment of Indonesian students as lifelong students who have global competence and behave in accordance with the values of Pancasila with six main characteristics: faith, fear of God Almighty, and noble character, global diversity, mutual cooperation, independent, critical reasoning. and creative. Character education in the formation of Pancasila student profiles has actually been attempted, both in the learning process in the classroom and outside the classroom. The formulation of the Pancasila Student profile was made with the aim of being a compass for Indonesian educators and students. All learning, programs, and activities in the education unit aim at the end of the Pancasila student profile. These efforts can be done through example and habituation which in its implementation cannot be separated from the guidance of a teacher (pamong). In accordance with the motto of Ki Hajar Dewantara "ing ngarso sung tulodo, ing madya mangun karso, tut wuri handayani which means in front of being an example, in the middle building enthusiasm in the back giving encouragement". From the results of the literature study it was found that Ki Hajar Dewantara's thoughts on education were very relevant to be applied where according to him that independent 
education was a deliberate effort to advance the life and growth of character (feel, mind, spirit) and the child's body by way of teaching, example, and habituation should not be accompanied by orders and coercion. This thinking is in line with the mandate of the President of the Republic of Indonesia as stated in the Minister of Education and Culture Regulation No. 20 of 2018 concerning the determination of the Pancasila student profile. The Pancasila student profile aims to support the President's Vision and Mission to realize an Advanced Indonesia that is sovereign, independent and has personality. The embodiment of Indonesian students as lifelong students who have global competence and behave in accordance with the values of Pancasila. contains theories that are relevant to the research to be carried out. It is hoped that this literature study will be able to show the Internalization of Ki Hajar Dewantara's educational philosophy in realizing the Pancasila Student Profile

Keywords: Profile of Pancasila Students, Ki Hajar Dewantara's Philosophy, Character Education

\section{PENDAHULUAN}

Peraturan Menteri Pendidikan dan Kebudayaan No 22 Tahun 2020 tentang Rencana Strategis Kementrian Pendidikan dan Kebudayaan Tahun 2021-2024 menyebutkan tentang istilah Profil Pelajar Pancasila. Visi Pendidikan Indonesia adalah mewujudkan Indonesia maju yang berdaulat, mandiri dan berkepribadian melalui terciptanya pelajar Pancasila yang bernalar kritis, kreatif, mandiri, beriman, bertakwa kepada Tuhan yang Maha Esa, dan berakhlak mulia, bergotong royong dan berkebudayaan global. Yang dimaksud dengan Profil Pelajar Pancasila adalah perwujudan pelajar Indonesia sebagai pelajar sepanjang hayat yang memiliki kompetensi global dan berperilaku sesuai dengan nilai-nilai Pancasila, dengan enam ciri utamanya yaitu : beriman bertakwa kepada Tuhan YME dan berakhlak mulia, berkebhinekaan global, bergotong royong, mandiri, bernalar kritis dan kreatif.

Masalah Radikalisme dan perundungan yang marak terjadi dianggap sebagai pelanggaran terhadap nilai-nilai Pancasila, Kemendikbud sebagai Kementrian yang yang menaungi dunia pendidikan telah merancang upaya-upaya dan kebijakan-kebijakan untuk mengatasi problematika ini, salah satunya ialah gagasan sekolah penggerak yang akan mewujudkan profil peajar Pancasila yang terdiri atas enam dimensi, yaitu : beriman bertakwa kepada Tuhan YME dan berakhlak mulia, berkebhinekaan global, bergotong royong, mandiri, bernalar kritis dan kreatif. Enam dimensi ini disebut sebagai indikator Profil Pelajar Pancasila.

Pendidikan hakikatnya adalah usaha sadar dan terencana untuk mewujudkan suasana belajar dan proses pembelajaran agar peserta didik secara aktif mengembangkan potensi dirinya untuk memiliki potensi spiritual keagamaan, pengendalian diri, kepribadian, kecerdasan, akhlak mulia, serta ketrampilan yang diperlukan. Pada umumnya pembelajaran disekolah berfokus pada penyelesaian materi tujuan pembelajaran, dan kita lalai mengembangkan potensi diri siswa hingga budi pekerti siswa.

Untuk menerapkan filosofi pendidikan nasional Ki Hajar Dewantara diharapkan mampu menanamkan budi pekerti budi pekerti siswa dan meningkatkan daya nalar kritis sehingga mencerminkan pelajar yang cerdas dan berbudi luhur. Pendidikan yang baik akan menjadikan negara yang berbudaya dan memiliki peradaban yang baik di masa mendatang.

Pelajar Pancasila adalah perwujudan pelajar Indonesia sebagai pelajar sepanjang hayat yang memiliki kompetensi global dan berperilaku sesuai dengan nilai-nilai Pancasila dengan enam ciri utama : beriman, bertakwa kepada Tuhan Yang Maha Esa dan berakhlak mulia, berkebhinekaan global, bergotong royong, mandiri, bernalar kritis dan kreatif. Menurut Ki hajar Dewantara pengaruh pengajaran itu umumnya memerdekan manusia atas hidupnya sejak lahir, sedang merdekanya hidup batin itu terdapat dari pendidikan. Manusia merdeka yaitu manusia yang hidupnya lahir batin tidak tergantung kepada orang lain, akan tetapi bersandar akan kekuatannya sendiri.

Beliau juga berpendapat bahwa pendidikan adalah tempat persemaian segala benihbenih kebudayaan yang hidup dalam masyarakat kebangsaan. Pendidikan dan kebudayaan 
merupakan dua hal yang tidak dapat dipisakan. Pendidikan menjadi landasan pembentukan peradaban bangsa. Pekerjaaan seorang guru disekolah bukan hanya bagaimana anak bersekolah, ujian hasilnya baik tetapi pekerjaan seorang guru adalah pekerjaan untuk menjemput kebudayaan yang dicita-citakan atau dengan kata lain pekerjaan untuk membentuk peradaban.

Ki Hajar Dewantara memberikan sebuah garis bawah mengenai istilah pengajaran dan juga pendidikan,yang kita sering menyamakannya. Agar nantinya tidak memperkeruh makna asli dari pendidikan itu sendiri. Pengajaran diartikan sebagai sebuah bagian dari pendidikan, dimana pengajaran memiliki spektrum pendidikan yang dilakukan dengan cara memberikan ilmu atau pengetahuan serta kecakapan, yang keduanya akan berfaedah untuk kehidupan anak didik baik lahir maupun batin, Singkatnya pengajaran menekankan pada wawasan, sementara pendidikan lebih berfokus pada karakter. Atau dengan kata lain pengajaran bersifat memerdekakan manusia dari aspek hidup lahiriah (kemiskinan dan kebodohan), sedangkan pendidikan mengarah pada memerdekakan manusia dari apsek hidup batin (otonomi berpikir dan mengambil keputusan, martabat, mentalitas demokratik)

Manusia yang merdeka adalah manusia yang hidupnya secara lahir dab batin tidak terganggu kepada orang lain, akan tetapi ia mampu bersandar dan berdiri diatas kakinya sendiri, artinya sistema pendidikan mampu menjadikan setiap individu hidup mandiri dan berpikir sendiri.

Pendidikan dan pengajaran merupakan usaha persiapan dan persediaan untuk segala kepentingan hidup manusia baik dalam hidup bermasyarakat maupun hidup berbudaya dalam arti yang seluas-luasnya. Ki Hajar Dewantara memiliki keyakinan bahwa untuk menciptakan manusia Indonesia yang beradab maka pendidikan menjadi salah satu kunci utama untuk mencapainya, pendidikan dapat menjadi ruang berlatih dan bertumbuhnya nilai-nilai kemanusiaan yang dapat diteruskan atau diwariskan.

Pendidikan menurut Ki Hajar Dewanatara adalah sebuah tuntunan yang menuntun segala kodrat yang ada pada anak didik agar mereka sebagai manusia dan sebagai masyarakat dapat menemukan kesejahteraan serta kebahagiaan hidup setinggi-tingginya. Karena pendidikan merupakan sebuah tuntunan, tugas pendidik adalah menemukan potensi terbaik yang ada di dalam diri peserta didik serta menumbuhkan potensi tersebut sesuai dengan kodrat mereka, pendidik hanya merawat tumbuhnya kodrat tersebut. Meski mereka memperoleh pendidikan dengan guru serta mengenyam sekolah yang sama, mereka akan tumbuh dengan jalan mereka sendiri-sendiri.

Karena pendidikan adalah suatu tuntunan dalam hidup tumbuhnya anak-anak, mengandung pengertian bahwa hidup tumbuhnya anak-anak itu terletak diluar kecakapan atau kehendak para pendidik. Kaum pendidik hanya dapat menuntun tumbuhnya atau hdupnya kekuatan-kekuatan itu agar dapat memperbaiki lakunya (buikan dasarnya) hidup dan tumbuhnya itu. Dari konsepsi tersebut dapat diambil kesimpulan bahwa Ki Hajar Dewantara ingin a) menempatkan anak didik sebagai pusat pendidikan b) memandang pendidikan sebagai suatu proses yang dengan demikian bersifat dinamis dan c) mengutamakan keseimbangan antar cipta, rasa dan karsa dalam diri anak. Dengan demikian pendidikan yang dimaksud oleh Ki Hajar Dewantara memperhatikan keseimbangan cipta, rasa, dan karsa tidak hanya sekedar proses alih ilmu pengetahuan saja atau tranfer of knowledge, tetapi sekaligus pendidikan juga sebagai proses transformasi nilai (transformation of Value). Dengan kata lain pendidikan adalah proses pembentukan karakter manusia agar menjadi sebenar-benar manusia

Berdasarkan latar belakang diatas maka artikel ini berfokus pada bagaimanakah internalisasi filosofi pendidikan Ki Hajar Dewantara dalam menwujudkan profil pelajar Pancasila sesuai dengan amanat Peraturan Menteri Pendidikan dan kebudayaan No 20 Tahun 2020 Tentang Rencana strategis Pendidikan dan Kebudayaan Tahun 2021-2024 dan sesuai dengan visi Pendidikan Indonesia. 


\section{METODE PENELITIAN}

Metode yang digunakan dalam penulisan artikel ini menggunakan metode penelitian pustaka (Library research). Menurut (Milya and Asmendri, 2020) menyatakan bahwa penelitian kajian pustaka didapat dari berbagai literatur seperti buku referensi, artikel, hasil penelitian yang sesuai catatan, dan berbagai jurnal yang informasi-informasi dari literatur dikumpulkan yang sesuai dengan kegiatan penelitian.Teknik pengumpulan data yang digunakan adalah dokumentasi yaitu dengan mengumpulkan sumber-sumber dokumen literatur. Sumber studi literatur ini berupa artikel jurnal online, berita online, hal website, dokumen serta peraturan perundang-undangan pemerintah online dan buku-buku yang berhubungan dengan profil pelajar Pancasila dan filosofi pemikiran Ki Hajar Dewantara dalam mewujudkan profil Pelajar Pancasila. Penelitian ini secara sistematis dilakukan dengan mengumpulkan, mengolah, dan menyimpulkan data dengan menggunakan kajian pustaka untuk memberikan informasi yang benar dan tepat yang digunakan untuk menjawab dari permasalahan yang diperoleh. Dengan kata lain penelitian pustaka adalah penelitian yang dilakukan dengan cara mengumpulkan, mengolah, dan menyimpulkan data yang sesuai dengan literatur-literatur yang mendukung

\section{HASIL DAN PEMBHASAN}

\section{Hasil Penelitian}

Berdasarkan hasil study pustaka dari berbagai referensi dan artikel penelitian terdahulu berkaitan dengan Internalisasi Filosofi Pendidikan Ki Hajar Dewantara dalam mewujudkan profil pelajar Pancasila, berikut temuan dalam kajian tersebut disajikan dan direfleksi atas studi literatur yang dilakukan. Hasil penelitian disajikan pada tabel 1 di bawah ini

\begin{tabular}{|c|c|c|c|}
\hline No & Artikel Penelitian & Temuan & Refleksi \\
\hline 1 & $\begin{array}{l}\text { Relevansi Pemikiran Ki } \\
\text { hajar Dewantara dengan } \\
\text { Konsep Merdeka Belajar } \\
\text { Nadhim Makarim Eka } \\
\text { Prasetya Berkamsyah) } 2020\end{array}$ & $\begin{array}{l}\text { Merdeka yang dicanangkan } \\
\text { oleh Nadhim Makarim } \\
\text { Menteri Pendidikan Ristek } \\
\text { dan Teknologi memuat } \\
\text { kebijakan yang humanis } \\
\text { yang berupaya } \\
\text { mengembalikan kembali } \\
\text { esensi belajar mengajar } \\
\text { yakni pendidik dan peserta } \\
\text { didik sama-sama belajar. } \\
\text { Menurut Ki Hajar } \\
\text { Dewantara pendidikan } \\
\text { merupakan sebuah tuntunan } \\
\text { yang menuntun tumbuh dan } \\
\text { berkembangnya kodrat yang } \\
\text { ada pada peserta didik dan } \\
\text { mengantarkannya untuk } \\
\text { mencapai kesempurnaan } \\
\text { hidup. Dari sini dapat dilihat } \\
\text { pemikiran Ki Hajar } \\
\text { Dewantara yang lebih } \\
\text { mengedepankan } \\
\text { perkembangan peserta } \\
\text { didik. Konsep Merdeka } \\
\text { Belajar yang digagas oleh } \\
\text { Kementrian Pendidikan, } \\
\text { rupanya seirama dengan apa } \\
\text { yang digaungkan oleh Ki }\end{array}$ & $\begin{array}{l}\text { Melihat esensi utama } \\
\text { dari merdeka belajar } \\
\text { yang mengedepankan } \\
\text { kebebasan berfikir serta } \\
\text { berinovasi bagi guru dan } \\
\text { murid akan sangat efektif } \\
\text { untuk mengeksplorasi } \\
\text { potensi dari peserta didik } \\
\text { itu sendiri. } \\
\text { Dari berbagai pemaparan } \\
\text { mengenai pemikiran Ki } \\
\text { Hajar Dewantara dan } \\
\text { konsep Merdeka Belajar } \\
\text { terdapat beberapa point } \\
\text { yang saling sejajar secara } \\
\text { esensi maupun } \\
\text { muatannya. }\end{array}$ \\
\hline
\end{tabular}


Vol. 1 No. 3 Desember 2021, e-ISSN : 2797-8842 | p-ISSN : 2797-9431

\begin{tabular}{|c|c|c|c|}
\hline & & $\begin{array}{l}\text { Hajar Dewantara dalam } \\
\text { beberapa tahun silam yang } \\
\text { dirasa masih sangat relevan } \\
\text { untuk diterapkan di masa } \\
\text { sekarang ini. }\end{array}$ & \\
\hline 2 & $\begin{array}{l}\text { Análisis Nilai-nilai } \\
\text { Pendidikan Karakter pada } \\
\text { Konsep Trikon dan } \\
\text { Relevansinya terhadap } \\
\text { Pendidikan Agama Islam } \\
\text { (Kajian Pemikiran Ki Hajar } \\
\text { Dewantara oleh Nadhila } \\
\text { Cahyaning Putri Pembayun) } \\
2018\end{array}$ & $\begin{array}{l}\text { Nilai-nilai Pendidikan } \\
\text { Karakter pada Konsep } \\
\text { Trikon adalah Nilai-nilai } \\
\text { karakter yang merupakan } \\
\text { hasil dari análisis terhadap } \\
\text { Konsep Trikon yang } \\
\text { dikemukakan oleh Ki Hajar } \\
\text { Dewantara }\end{array}$ & $\begin{array}{l}\text { Pendidikan Karakter } \\
\text { menjadi tema utama } \\
\text { yang dibahas untuk } \\
\text { Kementrian Pendidikan } \\
\text { dan Budaya dalam } \\
\text { rangka memperingati } \\
\text { Hari Pendidikan } \\
\text { Nasional tahun 2010, hal } \\
\text { ini sebagai bukti bahwa } \\
\text { pendidikan karakter } \\
\text { menjadi hal yang sangat } \\
\text { penting dalam dunia } \\
\text { pendidikan. Dan tentang } \\
\text { Pendidikan karakter ini } \\
\text { telah lebih dulu di } \\
\text { cetuskan oleh Ki Hajar } \\
\text { Dewantara }\end{array}$ \\
\hline 3 & $\begin{array}{l}\text { Harmonisasi Nilai-nilai } \\
\text { Pancasila dalam sistem } \\
\text { Among sesuai dengan alam } \\
\text { pemikiran Pendidikan Ki } \\
\text { Hajar Dewantara (Widya } \\
\text { Noventari) } 2016\end{array}$ & $\begin{array}{l}\text { Ki Hajar Dewantara } \\
\text { menawarkan Konsep } \\
\text { pendidikan dengan sistem } \\
\text { Among yang menyokong } \\
\text { kodrat alam peserta didik } \\
\text { bukan dengan "perintah } \\
\text { pelaksana" tetapi dengan } \\
\text { tuntunan agar berkembang } \\
\text { lahir dan batin anak menurut } \\
\text { kodratnya secara subur dan } \\
\text { selamat. Sistem Among } \\
\text { yang telah dikonsepkan oleh } \\
\text { Ki Hajar Dewantara selalu } \\
\text { selaras dengan apa yang } \\
\text { disebut sebagai dasar negara } \\
\text { Indonesia yakni Pancasia. } \\
\text { Sistem Among seakan } \\
\text { menggambarkan bagaimana } \\
\text { sebuah sistema pendidikn di } \\
\text { laksanakan sesuai dengan } \\
\text { budaya luhur bangsa yang } \\
\text { juga menjiwai tiap sila-sila } \\
\text { dalam Pancasila }\end{array}$ & $\begin{array}{l}\text { Sistem among } \\
\text { merupakan cara } \\
\text { mendidik anak dengan } \\
\text { dasar kemerdekaan dan } \\
\text { kebebasan agar anak } \\
\text { didik dapat tumbuh } \\
\text { sesuai kodrat pribadinya. } \\
\text { Sistem among patut } \\
\text { dijadikan sebagai cara } \\
\text { mendidik untuk } \\
\text { menciptakan jiwa } \\
\text { merdeka sehingga } \\
\text { menjadikan siswa lebih } \\
\text { berani belajar apa yang } \\
\text { dikehendakinya }\end{array}$ \\
\hline 4 & $\begin{array}{l}\text { Analisis Konsep Pemikiran } \\
\text { Ki Hajar Dewantara Dalam } \\
\text { Perspektif Pendidikan } \\
\text { Karakter (Sukri, Trisakti } \\
\text { Handayani, Agus Tinus, } \\
\text { FKIP Universitas }\end{array}$ & $\begin{array}{l}\text { Salah satu konsep Pemikiran } \\
\text { Ki Hajar Dewantara } \\
\text { diaplikasikan lewat rumusan } \\
\text { Pancasila, mengamalkan } \\
\text { Pancasila dengan baik dan } \\
\text { benar bisa membentuk } \\
\text { manusia berbudaya yang }\end{array}$ & $\begin{array}{l}\text { Pendidikan karakter } \\
\text { merupakan upaya } \\
\text { terencana untuk } \\
\text { menjadikan pesera didik } \\
\text { mengenal,peduli dan } \\
\text { menginternalisasi nilai- } \\
\text { nilai sehingga peserta }\end{array}$ \\
\hline
\end{tabular}


Vol. 1 No. 3 Desember 2021, e-ISSN : 2797-8842 | p-ISSN : 2797-9431

\begin{tabular}{|l|l|l|}
\hline Muhammadiyah Malang) & cocok dengan bangsa & didik menjadi insan \\
& Indonesia. Slogan Tut Wuri & kamil. Tugas guru \\
& Handayani sudah selayaknya & sebagai ujung tombak \\
& dimaknai secara mendalam & dalam pendidikan sangat \\
& oleh para stake holder & diperlukan dalam \\
& pendidikan terutama guru & mewujudkan karakter \\
& sebagai ujung tombaknya, & peserta didik \\
& sehingga tercipta pendidikan & \\
& yang mampu memerdekakan & \\
& manusia manusia seperti apa \\
& yang dicita-citakan Ki Hajar & \\
& Dewantara & \\
\hline
\end{tabular}

\section{Pembahasan}

\section{Penerapan Profil Pelajar Pancasila di Sekolah}

Profil pelajar Pancasila merupakan upaya menerjemahkan tujuan dan visi pendidikan ke dalam format yang lebih mudah dipahami oleh seluruh pemangku kepentingan pendidikan. Rumusan profil pelajar Pancasila dibuat dengan tujuan sebagai kompas bagi pendidik dan pelajar Indonesia. Segala pembelajaran, program, dan kegiatan disatuan pendidikan bertujuan akhir ke profil pelajar Pancasila.dengan enam dimensi yang harus dimiliki seorang pelajar, antara lain : beriman dan bertakwa kepada Tuhan Yang Maha Esa dan berakhlak mulia, berkebhinekaan global, gotong royong, mandiri, bernalar kritis, kreatif

Pendidikan yang diterapkan harus memerdekakan, yang terinspirasi dari pemikiran Ki Hajar Dewantara. Menurut beliau pendidikan merdeka itu berdaya upaya dengan sengaja untuk memajukan hidup tumbuhnya budi pekerti (rasa, fikiran, rokh) dan badan anak dengan jalan pengajaran, teladan dan pembiasaan jangan disertai dengan perintah dan paksaan.

Memperlakukan anak sesuai dengan kodrat alam yang ada pada diri anak dan sesuai dengan keunikan masing-masing pribadi anak serta menggali potensi-potensi yang dimiliki oleh anak sehingga mereka bisa mengembangkan potensi yang dimilikinya di dalam kehidupan masyarakat. Dengan kata lain sekolah sebagai sarana mempertajam atau mengasah potensi yang dimiliki anak sesuai dengan kemampuan yang sudah dimiliki agar bisa mengambil bagian dalam kehidupan masyarakat.

Profil pelajar Pancasila adalah karakter dan kemampuan yang dibangun dalam keseharian dan dihidupkan dalam diri setiap individu pelajar melalui budaya sekolah, pembelajaran intrakurikuler, kokurikuler, maupun ekstrakurikuler. Budaya sekolah yang dimaksud adalah iklim sekolah, kebijakan, pola interaksi dan komunikasi, serta norma yang berlaku di sekolah. Intrakurikuler meliputi muatan pelajaran kegiatan atau pengalaman belajar. Yang dimaksud dengan projek yaitu pembelajaran berbasis projek yang konstektual dan interaksi dengan lingkungan sekitar. Ekstrakurikuler yaitu kegiatan untuk mengembangkan minat dan bakat pesrta didik.

Sebelum profil pelajar Pncasila ini diterapkan di sekolah perlu adanya pemahaman tentang merdeka belajar yang sekarang ini mulai diperdengarkan dan mulai diterapkan di berbagai sekolah rujukan dalam menciptakan pembeajaran paradigma baru di sekolah. Merdeka belajar dapat dikatakan sebagai langkah awal sebelum profil pelajar Pancasila diterapkan.

Konsep merdeka belajar menurut Ki Hajar Dewantara adalah memerdekakan anak dalam belajar yaitu melalui pembebasan terhadap hal-hal yang disukainya atau diminatinya bahkan bakatnya. Konsep merdeka belajar yang diterapkan dalam kurikulum paradigma baru terinspirasi dari pemikiran Ki Hajar Dewantara "Ing Ngarso Sung Tulodho, Ing Madyo Mangun Karso, Tut Wuri Handayani”. Dalam konsep pemikiran Ki Hajar Dewantara ini cukup jelas bahwa pendidik mempunyai tanggung jawab yang besar terhadap pembentukan nilai karakter peserta didiknya. Pendidik menjadi teladan apabila berada di depan, menjadi motivator atau semangat jika ditengah, pendidik menjadi pendorong dari belakang peserta didik jika dibelakang, dengan berbagai dukungan agar peserta didik dapat mandiri. 
Hal ini selaras dengan merdeka belajar yang dicanangkan oleh Nadhim Makarim Menteri Pendidikan Ristek dan Teknologi memuat kebijakan yang humanis yang berupaya mengembalikan kembali esensi belajar mengajar yakni pendidik dan peserta didik sama-sama belajar. Dimana menurut Ki Hajar Dewantara pendidikan merupakan sebuah tuntunan yang menuntun tumbuh dan berkembangnya kodrat yang ada pada peserta didik dan mengantarkannya untuk mencapai kesempurnaan hidup. Dari sini dapat dilihat pemikiran Ki Hajar Dewantara yang lebih mengedepankan perkembangan peserta didik.Hal ini sebagai bukti bahwa Konsep Merdeka Belajar yang digagas oleh Kementrian Pendidikan, rupanya seirama dengan apa yang digaungkan oleh Ki Hajar Dewantara dalam beberapa tahun silam yang dirasa masih sangat relevan untuk diterapkan di masa sekarang ini.

Dalam pembentukan nilai karakter peserta didik yang menjadi tanggung jawab pendidik, dapat terealisasi dengan penerapan profil pelajar Pancasila ke dalam ranah pendidikan. Profil pelajar Pancasila dapat diterapkan pada jenjang pendidikan dari usia dini sampai dengan perguruan tinggi, dapat juga dijadikan sebagai pendidikan sepanjang hayat yaitu pendidikan yang dilakukan sampai akhir usianya. Salah satu konsep Pemikiran Ki Hajar Dewantara diaplikasikan lewat rumusan Pancasila, mengamalkan Pancasila dengan baik dan benar bisa membentuk manusia berbudaya yang cocok dengan bangsa Indonesia. Slogan Tut Wuri Handayani sudah selayaknya dimaknai secara mendalam oleh para stake holder pendidikan terutama guru sebagai ujung tombaknya, sehingga tercipta pendidikan yang mampu memerdekakan manusia manusia seperti apa yang dicita-citakan Ki Hajar Dewantara

Profil pelajar Pancasila merupakan mandat dari Presiden Republik Indonesia yang tertuang dalam Peraturan menteri Pendidikan dan Kebudayaan No 20 Tahun 2018 tentang penetapan profil pelajar Pancasila. Di dalam arahan dan visinya, beliau mengatakan bahwa "sistem pendidikan Nasional harus mengedepankan nilai-nilai Ketuhanan, yang berkarakter kuat dan berakhlak mulia, serta unggul dalam inovasi dan teknologi". Hal-hal yang melatar belakangi dibentuknya profil pelajar Pancasila yaitu pendidikan karakter mulai terkikis oleh waktu dan semakin dilupakan. Yang didalam pendidikan karakter inilah terwujud pelajar Pancasila yang menjadi profil bangsa Indonesia. Sumber Daya Manusia yang unggul merupakan tujuan akhir dari profil Pelajar Pancasila, seorang peserta didik dinyatakan unggul apabila menerapkan belajar sepanjang hayat yang memiliki kompetensi global dan berperilaku sesuai dengan nilai-nilai Pancasila.

Sehingga jelas bahwasannya profil pelajar Pancasila bertujuan mendukung Visi dan Misi Presiden untuk mewujudkan Indonesia Maju yang berdaulat, mandiri dan berkepribadian. Perwujudan pelajar Indonesia sebagai pelajar sepanjang hayat yang memiliki kompetensi global dan berperilaku sesuai dengan nilai-nilai Pancasila. Penamaan profil pelajar Pancasila bertujuan untuk menguatkan nilai-nilai luhur Pancasila dalam diri setiap individu pelajar. Pancasila adalah satu kata yang sesuai untuk merangkum seluruh karakter dan kompetensi yang diharapkan untuk dimiliki setiap pelajar Indonesia.

Penerapan Profil Pelajar Pancasila di sekolah dapat digambarkan dalam diagram berikut:

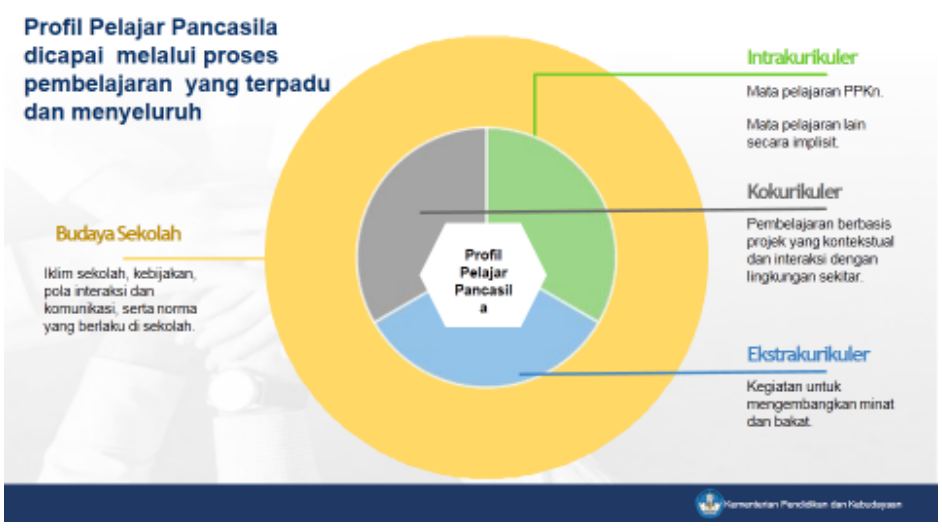




\section{Dimensi-Dimensi Profil Pelajar Pancasila}

Dalam peraturan Menteri Pendidikan dan Kebudayaan No 22 Tahun 2020 tentang Rencana Strategis Kementerian Pendidikan dan Kebudayaan Tahun 2020-2024 menyatakan "Pelajar Indonesia merupakan pelajar sepanjang hayat yang memiliki kompetensi global dan berperilaku sesuai nilai-nilai Pancasila".

Pernyataan ini memuat tiga kata kunci, yaitu : pelajar sepanjang hayat, kompetensi global, dan pengamalan nilai-nilai Pancasila.

Dengan mengacu kepada hal tersebut maka disusunlah dimensi-dimensi profil pelajar Pancasila yang meliputi 6 dimensi, yang dapat digambarkan dalam grafik sebagai berikut :

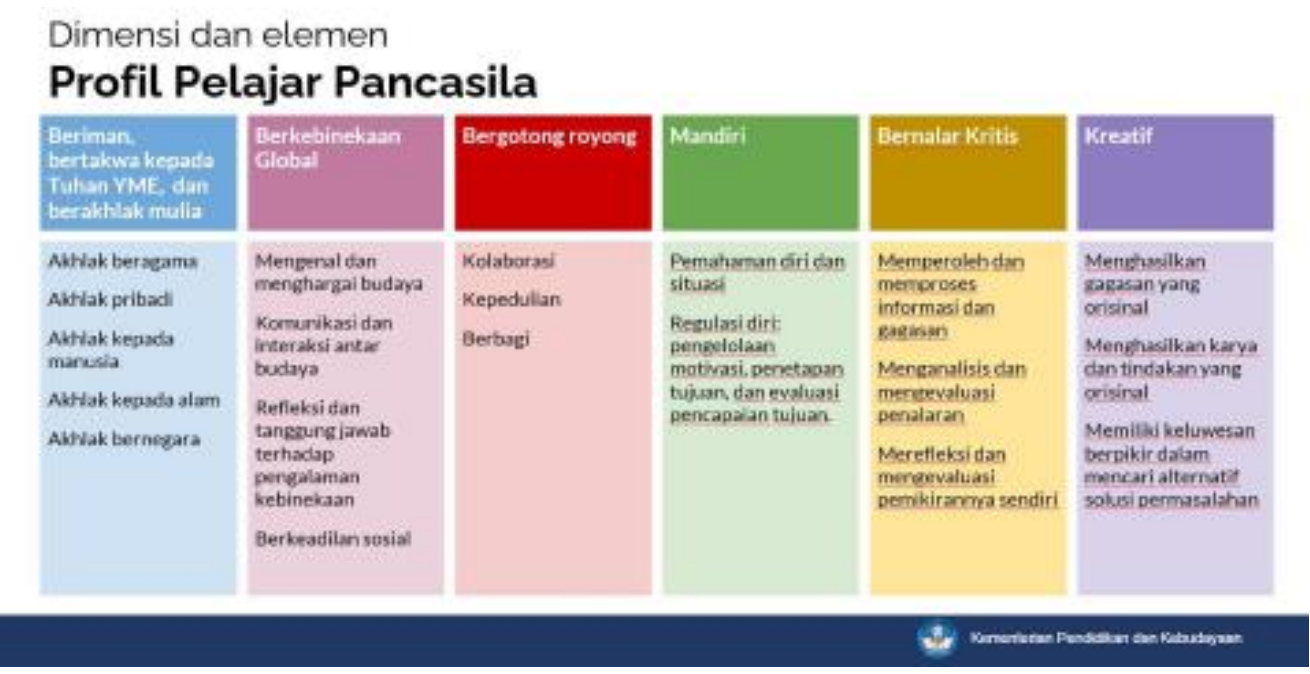

Kalau digambarkan dalam grafik 6 dimensi profil pelajar Pancasila digambarkan sebagai berikut :

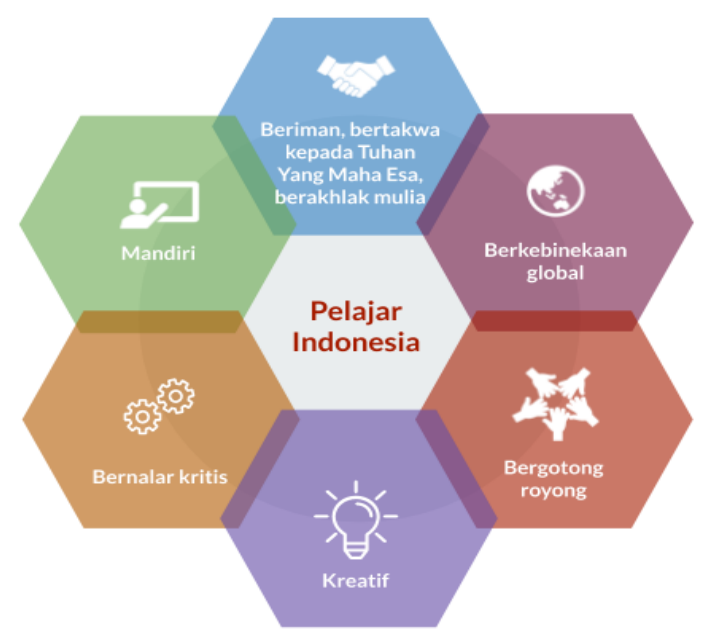

Dengan penjelasan perdimensi sebagai berikut :

\section{Beriman, Bertakwa kepada Tuhan Yang Maha Esa, dan Berakhlak Mulia}

Peserta didik dengan dimensi ini diharapkan dapat mengamalkan nilai-nilai agama dan kepercayaannya sebagai bentuk religiusitasnya, percaya dan menghayati keberadaan Tuhan serta memperdalam ajaran agamanya yang tercermin dalam perilakunya sehari-hari sebagai bentuk penerapan pemahaman terhadap ajaran agamanya. Dalam usahanya memperkuat iman dan takwa kepada Tuhan Yang Maha Esa ditunjukkan dengan peserta didik dapat menghargai segala bentuk ciptaanNya, baik itu alam tempat ia tinggal, manusia lain dan yang tidak boleh dilupakan dirinya sendiri. Dengan menghargai hubungannya dengan Tuhan Yang Maha Esa, dirinya sendiri, orang lain, serta alam, maka peserta didik dapat memenuhi dimensi ini 
Untuk menumbuhkan Profil Pelajar Pancasila, Beriman dan Bertakwa Kepada Tuhan Yang Maha Esa dimulai dari pemberian arahan, pemahaman, serta pembiasaan siswa baik dirumah, sekolah, atau lingkungan masyarakat. Bebrapa hal yang bisa diterapkan di sekolah dalam kegiatan belajar mengajar dari pemberian materi agama, melatih keikhlasan dengan membantu orang lain, menggalang donasi setiap hari jumat, hingga membiasakan diri untuk berperilaku 5S (Senyum, Salam, Sapa, sopan dan santun) di lingkungan Sekolah.

\section{Berkebhinekaan Global}

Murid dengan dimensi profil ini merupakan seorang murid yang berbudaya, memiliki identitas diri yang matang, mampu menunjukkan dirinya sebagai representasi budaya luhur bangsanya, serta terbuka terhadap keberagaman budaya daerah, nacional dan global. Hal ini dapat diwujudkan dengan kemampuan berinteraksi secara positif antar sesama, memiliki kemampuan komunikasi interkultural, serta mampu memaknai pengalamannya di lingkungan majemuk sebagai kesempatan pengembangan dirinya.

Melalui profil kebhinekan tunggal, diharapkan siswa dapat menjaga budaya luhur, lokalitas dan identitas serta berpikiran terbuka ketika berinteraksi dengan budaya lain. Artinya siswa bisa mempertahankan budayanya sendiri tanpa harus menolak atau tidak mengahargai budaya lain.

Upaya menumbuhkan profil pelajar Pancasila bisa dilakukan melalui kegiatan yang mengenalkan budaya asli seperti ekstrakurikuler tarian daerah. Dengan begitu diharapkan siswa dapat menyadari bahwa setiap daerah mempunyai budayanya sendiri dan mereka tidak kaget ketika harus berhadapan dengan budaya lain di lingkungan berbeda

\section{Gotong Royong}

Merupakan kemampuan untuk melakukan kegiatan secara bersama-sama dalam team dan berkolaborasi untuk menjadikan segala pekerjaan menjadi mudah, cepat dan ringan. Pelaar Indonesia yang memiliki kemampuan gotong royong memiliki ciri-ciri antara lain : mampu melakukan kegiatan bersama-sama, berkolaborasi untuk mencapai kesejahteraan dan kebahagiaan orang-orang di sekitarnya, peduli terhadap lingkungannya, dan berkomitmen untuk bisa berkontribusi meringankan masalah yang dihadapi oleh orangorang di sekitarnya.

Untuk menumbuhkan gotong royong dan saling menghormati pada siswa, guru bisa menerapkannya dalam kegiatan pembelajaran sehari-hari, misalnya melalui metode belajar diskusi.

\section{Mandiri}

Seorang murid yang memiliki dimensi mandiri berarti murid tersebut mempunyai prakarsa atas pengembangan diri dan prestasinya dan didasari pada pengenalan kekuatan serta keterbatasan dirinya serta situasi yang dihadapi, dan bertanggung jawab atas proses dan hasilnya. Murid yang memiliki dimensi ini juga mampu mengelola dirinya sendiri (pikiran, perasaan, dan tindakan) untuk mencapai tujuan pribadinya atauapun tujuan bersama.

Dalam pembelajaran di kelas guru dapat melatih kemandirian siswa misalnya, mengumpulkan tugas tepat waktu, memulai kegiatan beajar mengajar tepat waktu, serta memberi hukuman bagi siswa yang tidak disiplin, bisa juga dengan melalui kegiatan ekstrakurikuler baik itu pramuka, paskibraka atau yang lainnya.

\section{Kreatif}

Seorang murid yang memiliki dimensi kreatif berarti mampu memodifikasi, menghasilkan sesuatu yang orisinal, bermakna, bermanfaat, dan berdampak untuk mengatasi berbagai persoalan baik untuk dirinya sendiri atau untuk lingkungan di sekitarnya.

Dalam dimensi ini pelajar Indonesia dituntut untuk mampu memodifikasi dan menghasilkan sesuatu yang orisinal, bermakna, bermanfaat, dan berdampak. Baik berupa gagasan,tindakan, maupun karya nyata

Guru memiliki peran penting dalam menumbuhkan kreativitas siswa dalam kegiatan pembelajaran di sekolah. Slah satu upaya yang dapat dilakukan yaitu dengan cara memberi kebebasan penugasan pada siswa untuk mengasah kreativitas mereka. Artinya siswa dapat 
menentukan pembelajaran sesuai dengan minatnya masing-masing dan guru dapat memberikan dasar serta konsep materi dalam kurikulum.

\section{Bernalar Kritis}

Dalam dimensi ini seorang siswa harus mampu menggunakan kemampuan nalar dirinya untuk memproses informasi, mengevaluasinya, hingga menghasilkan keputusan yang tepat untuk mengatasi berbagai persoalan yang dihadapinya. Murid tersebut mampu menyaring informasi, mengolahnya, mencari keterkaitan berbagai informasi, menganalisis serta, membuat kesimpulan berdasarkan informasi tersebut. Keterbukaan ini bermanfaat untuk kehidupan murid dimasa yang akan datang karena menumbuhkan murid yang terbuka, mau mengubah pendapatnya, serta menghargai pendapat orang lain.

Dalam dimensi ini bercirikan pada pelajar yang mampu melihat sesuatu dari berbagai sudut pandang dan terbuka terhadap pembuktian baru. Mampu berfikir sitematik dan saintifik, menarik kesimpulan dari fakta yang ada dan memecahkan masalah. Serta mampu memperoleh dan memproses informasi dan gagasan, menganalisis dan mengevaluasi penalaran, melakukan refleksi pemikiran dan proses berpikir serta mengambil keputusan

\section{KESIMPULAN}

Murid adalah anak didik yang memiliki kodrat alam yang selalu ingin merdeka sejak dari kandungan, ia menangis jika merasa kehausan hingga jiwa merdeka saat ia dewasa. Setiap anak memiliki kodaratnya masing-masing, maka tugas seorang pendidik adalah membimbing, menuntun, dan menjadi instruktur agar murid merdeka, sehingga mencapai keselamatan dan kebahagiaan yang setinggi-tingginya. Selain itu hal terpenting dalam pendidikan anak adalah memberikan pendidikan akhlak atau budi pekerti.

Peran orang tua ketika dirumah, peran guru ketika berada di sekolah dan peran masyarakat ketika dilingkungan sekitarnya sangat penting untuk mendidik dan dijadikan teladan atau panutan dalam melakukan sikap-sikap terpuji sehingga anak-anak memiliki sikap beriman dan bertakwa kepada Tuhan Yang Maha Esa, mandiri, gotong royong, bernalar kritis, kraeatif dan kebhinekaan glbal yang sesuai dengan profil pelajar Pancasila. Pendidikan yang kita berikan harus sesuai dengan tuntutan alam dan zamannya.

Pada saat ini anak harus memiliki ketrampilan abad 21 yaitu creative thinking, critical thinking, communication dan collaboration, artinya seorang siswa harus kreatif, mampu berfikir kritis, mampu berkomunikasi dengan baik, dan mampu berkolaborasi dengan baik. Seorang pendidik diibaratkan sebagai petani dan anak didik diibaratkan sebagai bibitnya. Petani harus merawat,memberi air, menyiangi gulma dan memberi pupuk agar kelak bisa berbuah dengan banyak dan baik, tetapi petani tidak mungkin dapat merubah bibit mangga yang ditanam berbuah menjadi buah anggur, karena itu merupakan kodrat alam dan dasar yang harus diperhatikan dalam pendidikan dan itu diluar kecakapan atau kehendak kita sebagai pendidik.

Pendidikan yang diberikan harus berpihak kepada anak, kita tidak bisa memaksakan kehendak yang kita inginkan. Anak adalah sang pemeran utama yang merupakan subjek bukan objek pendidikan. Guru dan murid harus berkolaborasi bersama untuk menggali dan mengembangkan potensi yang dimilikinya dan dapat mengakomodasi karakteristik masingmasing agar mencapai keselamatan dan kebahagiaan di dunia dan di akhirat. Guru harus bisa menerapkan filosofi dari Ki Hajar Dewantara "Ing Ngarso Sung Tulodho (di depan membei contoh), Ing Madyo Mangun Karso (ditengah memberi semangat), Tut Wuri handayani (dibelakang memberi dorongan)

\section{DAFTAR PUSTAKA}

Anindito Aditomo. (2021). Nilai-nilai Pancasila dalam Pembelajaran Merdeka Belajar. Kementrian Pendidikan dan Kebudayaan

Eka Prasetya Berkamsyah.(2020). Relevansi Pemikiran Ki Hajar Dewantara dengan konsep Merdeka Belajar Nadim Makarim. Prodi Pendidikan Agama Islam Fakultas Tarbiyah dan Keguruan Universitas Islam Negeri Sunan Ampel Surabaya 
I Made Sugiarta, Ida Bagus Putu Mardana, Agus Adiarta, I Wayan Artanayasa. (2019). Filsafat Pendidikan Ki Hajar Dewantara (Tokoh Timur). Jurnal Filsafat Indonesia, Vol 2 No 3 Th 2019.ISSN: E-ISSN 2620-7982.P-ISSN: 2620-7990

Ki Hadjar Dewantara. (2013). Pemikiran, Konsepsi, Keteladana, Sikap Merdeka bagian I Pendidikan. Universitas Sarjanawiyata Tamansiswa (UST-Press) bekerjasama dengan Majelis Luhur Persatuan Tamansiswa

Mamak Pintar, Blog Parenting kesehatan dan pendidikan. (http//mamakpintar.com). (2021). Profil Pelajar Pancasila Tujuan Akhir Sistem Pendidikan Indonesia

Nadhila Cahyaning Putri Pembayun. (2018). Analisis Nilai-nilai Pendidikan Karakter pada Konsep Trikon dan Relevansinya terhadap Pendidikan Agama Islam (Kajian Pemikiran Ki Hajar Dewantara). Jurusan Pendidikan Agama Islam Negeri (IAIN) Salatiga

Rusnani, Raharjo, Anis Suryaningsih, Widya Noventari.(2021). Intensifikasi Profil Pelajar Pancasila dan Implikasinya terhadap Ketahanan Pribadi Siswa. Jurnal Ketahanan Nasional. Vol. 27. No.2 : Hal 230-249.

Sukri, Trisakti Handayani,Agus Tinus. (2016). Analisis Konsep Pemikiran Ki Hajar Dewantara Dalam Perspektif Pendidikan Karakter. FKIP Universitas Muhammadiyah Malang Indonesia, http://ejournal.umm.ac.id/index.php/jurnalcivic hukum. Jurnal civic hukum. Volume I, Nomor 1 Mei 2016 P-ISSN 2623-0216

Widya Noventari. (2016). Harmonisasi Nilai-nilai Pancasila dalam sistema Among sesuai dengan alam pemikiran Pendidikan Ki Hajar Dewantara. JPK: Jurnal Pancasila dan Kewarganegaraan, Vol.1, No.1. ISSN 2527.7057 